Article

\title{
Improving Water Use Efficiency under Deficit Irrigation in the Jordan Valley
}

\author{
Maisa'a W. Shammout ${ }^{1, * \mathbb{D}}$, Tala Qtaishat ${ }^{2}$, Hala Rawabdeh ${ }^{2}$ and Muhammad Shatanawi ${ }^{2}$ \\ 1 Water, Energy and Environment Center, The University of Jordan, Amman 11942, Jordan \\ 2 Faculty of Agriculture, The University of Jordan, Amman 11942, Jordan; T.qtaishat@ju.edu.jo (T.Q.); \\ hl.rawabdeh@ju.edu.jo (H.R.); shatanaw@ju.edu.jo (M.S.) \\ * Correspondence: maisa_shammout@hotmail.com or m.shammout@ju.edu.jo; Tel.: +9-626-535-5000
}

Received: 16 September 2018; Accepted: 15 November 2018; Published: 21 November 2018

\begin{abstract}
The Jordan Valley is the prime irrigated agricultural area in Jordan which suffers shortage of water putting severe limitation on water allocation to farmers. To alleviate the problem, deficit irrigation was proposed for some vegetables such as bell pepper. Two field experiments in two growing seasons were conducted using bell pepper (Capsicum Annuиm L.) to assess the effect of deficit irrigation on yield, water use efficiency (WUE), and water productivity (WP). The treatments were three irrigation levels: $100 \%$ (T1), $80 \%$ (T2), and $60 \%$ (T3) of the calculated crop evapotranspiration (ETc) using class A pan method. A cost-benefit analysis was carried out to determine the best economically suitable season for crop growth. The yields in both seasons were higher under T1, but there was no difference in WUE and WP between T1 and T2. The yield, WUE, and WP for T3 were significantly lower than for $\mathrm{T} 1$ and $\mathrm{T} 2$. Therefore, it is recommended to irrigate at $80 \%$ of ET. The best results were obtained for the total gross margin and the net present value in the winter season. Using deficit irrigation reduces water usage without significant yield loss, meanwhile maintaining relatively high WUE and supporting the sustainability of agriculture in the Jordan Valley.
\end{abstract}

Keywords: agricultural sustainability; deficit irrigation; water use efficiency; water productivity; bell pepper

\section{Introduction}

Jordan is threatened by a scarcity of water, and the country is considered among the most water-stressed countries in the world with $100 \mathrm{~m}^{3}$ /year per capita of renewable water resources, far below the absolute threshold of $500 \mathrm{~m}^{3} /$ year [1]. Water stress and scarcity are becoming an acute and serious problem affecting the economic development, social cohesion, and political stability of the country. Because of scarcity, water supplies become more limited, and the potential for conflict arises among users, either within their water-use sector or with other sectors' users [2]. Water is withdrawn for many purposes, and priority in water allocation is given to domestic and industrial needs, while what is left is assigned to agriculture. As such, the share of the irrigated agriculture from the available water resources has dropped from $70 \%$ in 2008 to $53 \%$ in 2017 [3]. With the increase of demands for water for domestic and industrial uses due to population and economic growth, agriculture share will further decrease and will mainly depend on reclaimed water in addition to what is left from the surface water in the Jordan Valley. However, some surface and groundwater will be still used for irrigation on the basis of water rights and specific social conditions. Major current and future problems with water resources evolve from the pressure to meet the food, agriculture, and human needs of a fast-growing economy that generates more imbalances between water's demand and supply $[4,5]$.

Irrigation water management in an era of water scarcity will have to be carried out most efficiently, aiming at saving water and at maximizing its productivity [6]. In the future, water supplies for 
irrigation will be insufficient, and, therefore, irrigation management will shift from emphasizing the production per unit area towards maximizing the production per unit of water consumed, i.e., water productivity (WP) [7]. In addition, irrigated agriculture will need to adopt a new management paradigm based on an economic objective - the maximization of net benefits-rather than on the biological objective of maximizing yields [8]. To cope with these conditions, different options are available, including reduction of the irrigated areas, planting short season crops, and practicing deficit irrigation. Therefore, water demand for irrigation can be reduced, and the water saved can be used for other sectors or be diverted to irrigate additional land, meanwhile maintaining relatively high water use efficiency (WUE) and supporting the sustainability of irrigated agriculture. Deficit irrigation is the practice of deliberately under-irrigating a crop, to which water is applied below the evapotranspiration (ET) requirements, and irrigation water supply is reduced relative to that needed to meet maximum ET [9]. This practice may be more applicable than full irrigation when water supplies are limited or irrigation costs are high. Regulated deficit irrigation (RDI) is an optimizing strategy under which crops are allowed to sustain some degree of water deficit and yield reduction [10]. Under deficit irrigation, yield reduction will be insignificant compared with the benefits gained through diverting the saved water to irrigate other crops [11]. The concept of deficit irrigation (DI) was introduced in the 1970s and consists in reducing the amount of applied irrigation water [12]; therefore, it can be a way of increasing water productivity by providing higher yields per unit of water. Reference [13] in a review paper reports that DI has been widely investigated as a valuable and sustainable production strategy in dry regions. By limiting water applications to the drought-sensitive growth stages, this practice aims to maximize water productivity and to stabilize-rather than maximize-yields. Research results confirm that DI is successful in increasing water productivity for various crops without causing severe yield reductions [13]. In addition, applying deficit irrigation can require less labor than a pruning operation, thereby increasing crop profitability for farmers [14]. Deficit irrigation has proven successful with a number of crops which are relatively resistant to water stress or can avoid stress by deep rooting, allowing access to soil moisture that is lower in the soil profile [15]. In some circumstances, there may be no yield loss, and, for some crops, product quality may improve [16].

Several studies around the world have shown the efficacy of deficit irrigation in saving irrigation water and improving water use efficiency. A study on the effect of DI on bell pepper [17] found that there was a difference in yield between irrigation levels corresponding to $100 \%$ (T1) and $80 \%$ (T2) of crop evapotranspiration (ETc), while WUE was higher for the $80 \%\left(3.39 \mathrm{~kg} / \mathrm{m}^{3}\right)$ compared to $100 \%\left(3.13 \mathrm{~kg} / \mathrm{m}^{3}\right)$ treatment. Reference [18] found that the dry fruit weight of bell pepper at T2 at harvest was $66 \%$ of that of T3 (60\% of ETc) but did not differ significantly between T1 and T3. However, commercial yield (based on color production) was significantly higher at $\mathrm{T} 3$ than with the other two treatments, as the late water deficits imposed in T1 delayed harvest. A study on the effect of water stress on pepper plant [19] found that the $60 \%$ irrigation treatment provided a higher water use efficiency by $34 \%$ and $4.4 \%$ compared to the $100 \%$ treatment and the $75 \%$ treatment, respectively. The full irrigation treatment achieved the highest yield of 5.749 ton/ha compared to 5.535 ton/ha for the $75 \%$ treatment but with no significant difference. In a study on the influence of deficit irrigation on yield of eggplant grown under unheated greenhouse condition [20], researchers found that the highest yield averaging 62 ton/ha was obtained at $100 \%$ of ETc, while the water use efficiency for the $75 \%$ treatment was the highest $\left(13.16 \mathrm{~kg} / \mathrm{m}^{3}\right)$. The $75 \%$ application can be recommended as the most effective irrigation level for the eggplant to which drip irrigation is applied under scarce water resource and unheated greenhouse conditions. The concept of deficit irrigation has been successfully applied in Jordan on crops such as navel oranges [21], lemons [22], and tomatoes [23], for which no significant yield reduction was noticed at certain levels of DI.

The Jordan Valley (JV) is the main irrigated area in Jordan and is famous for off-season production of vegetables. One of the threats facing vegetable producers in the Valley is irrigation restrictions by the Jordan Valley Authority due to shortages in water supply. Protected cultivation is a steadily growing agricultural sector in Jordan, where extensive greenhouse areas of vegetables are located in the Valley. 
The type of structure primarily used in those areas is a low-cost, unheated plastic-covered structure, with soil-grown crops. It is estimated that the area devoted to intensive horticulture under plastic in the Jordan Valley corresponds to approximately 3500 ha of greenhouses [3]. The major vegetables grown under greenhouses in the JV include tomato, bell pepper, cucumber, and lettuce. Bell pepper (Capsicum Annиит L.) is a major greenhouse grown vegetable for the fresh and processing markets, accounting for $10.5 \%$ (48,848 tons) of Jordan vegetable exports [3]. Bell pepper is highly sensitive to water stress [24] and performs well with adequate supplies of water during its growth cycle [25]. The management of irrigation for bell pepper plants differs in terms of pepper varieties, length of growing cycle, soil-type environment, climatic region, irrigation type, and irrigation scheduling [26]. To achieve optimal bell pepper production and the best irrigation regime, there is a need for a comprehensive assessment of the yield, WUE, and fruit quality of the plant under deficit irrigation. Bell pepper was grown on loamy sand in the greenhouse at the Agricultural Research Station of the University of Jordan for the winter and spring seasons of 2015-2016.

The objective of this research was to study the optimal utilization of water resources for crops in order to improve water productivity by using a regulated deficit irrigation approach that is adaptable to the current conditions. Specifically, bell pepper yield, water use efficiency, and fruit size and quality in responses to deficit irrigation were determined. The research aimed also at assessing the relationship between revenue return and applied water and performing a cost-benefit analysis (CBA) to decide on which growing seasons the production of bell pepper is economically feasible. The research represents the integration of drip irrigation, ETc, and irrigation practices in terms of three deficit treatments $(\mathrm{T})$ at $100 \%$ of ETc (T1), $80 \%$ of ETc (T2), and $60 \%$ ETc (T3), based on the calculated ET using Class A evaporation pan method.

\section{Materials and Methods}

\subsection{Experimental Design and Irrigation Treatments}

This study was carried out in the winter season of 2015 and in the spring season of 2016 at the Agricultural research Station of the University of Jordan in the Central Jordan Valley. The station is located at latitude $30^{\circ}: 10^{\prime} \mathrm{N}$ and longitude $35^{\circ}: 37^{\prime} \mathrm{E}$ and at an altitude of $-230 \mathrm{~m}$ (below sea level). Figure 1 shows the location of the study area in the Jordan Valley. The soil of the study site is located within a soil mapping unit that has ustochreptic and ustollic camborthid with some ustic torriorthent and torrifluvent with a hyperthermal temperature regime [22]. The soil is a sandy loam, with sand, silt, and clay contents of $74 \%, 14.3 \%$ and $11.7 \%$, respectively, with an average field capacity of $18 \%$ and an average wilting point of $12 \%$ by volume. The source of irrigation water for the experiments was from King Abdullah Canal, with an average seasonal electrical conductivity (EC) of $1.74 \mathrm{dS} / \mathrm{m}$, while the average soil salinity was about $4.42 \mathrm{dS} / \mathrm{m}$. In the winter season experiment, the seedlings of bell pepper (C. Annuum L. cultivar Drago) were transplanted into the plots on 31 October 2015 and lasted till 8 March 2016, while for the spring season, transplanting was performed on 20 March 2016 and the last harvest was on 30 June 2016. The plants were vertically supported using the Dutch System, in which three stems per plant are vertically supported by guides, and the lateral stems are removed. Irrigation treatments consisted of three irrigation regimes: $100 \%$ (T1), $80 \%$ (T2), and 60\% (T3) of the calculated ETc using Class A pan method. The experiment was arranged in a completely randomized design with four replicates. Each plot had an area of $18 \mathrm{~m}^{2}$, with dimensions of $3 \times 6 \mathrm{~m}$. Each plot was irrigated using three drip lines spaced $1.0 \mathrm{~m}$ apart, with compensating emitters of $4 \mathrm{~L} / \mathrm{s}$ discharge placed every $0.5 \mathrm{~m}$ along the pipe length of $6.0 \mathrm{~m}$. For the first 4 weeks after transplanting, irrigation was uniformly applied to all treatments based on $100 \%$ replacement of ETc, and, afterwards, variable amounts of water were applied according the level of DI (T1, T2, and T3), while maintaining the frequency of two irrigations per week. A water-soluble fertilizer was applied weekly at the recommended rates. Other agricultural practices including weeding, pruning, and chemical spraying 
were carried out as needed or recommended. Figure 2 shows the expriment layout and the components of the irrigation system.

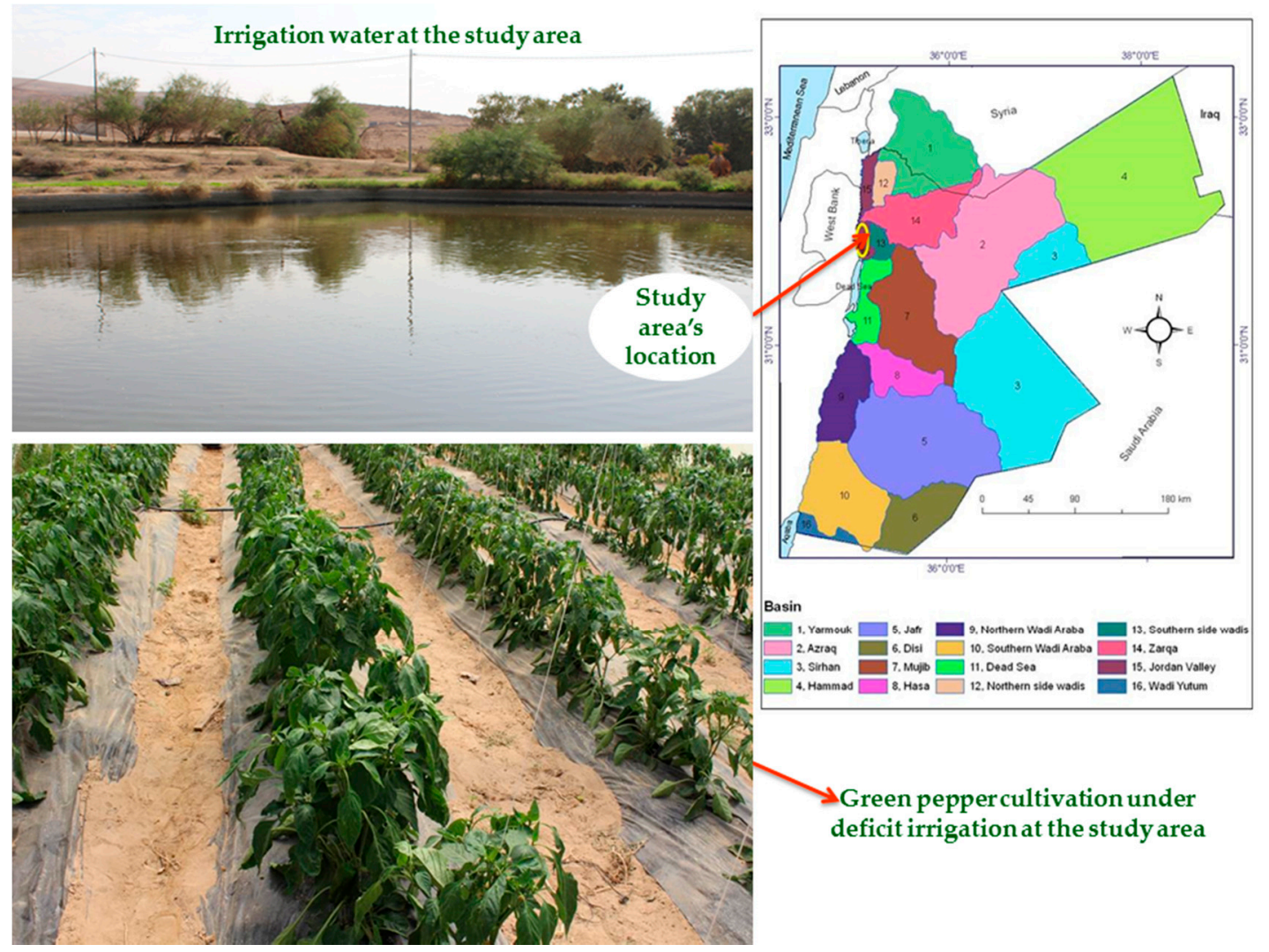

Figure 1. Location of the study area in the Jordan Valley.

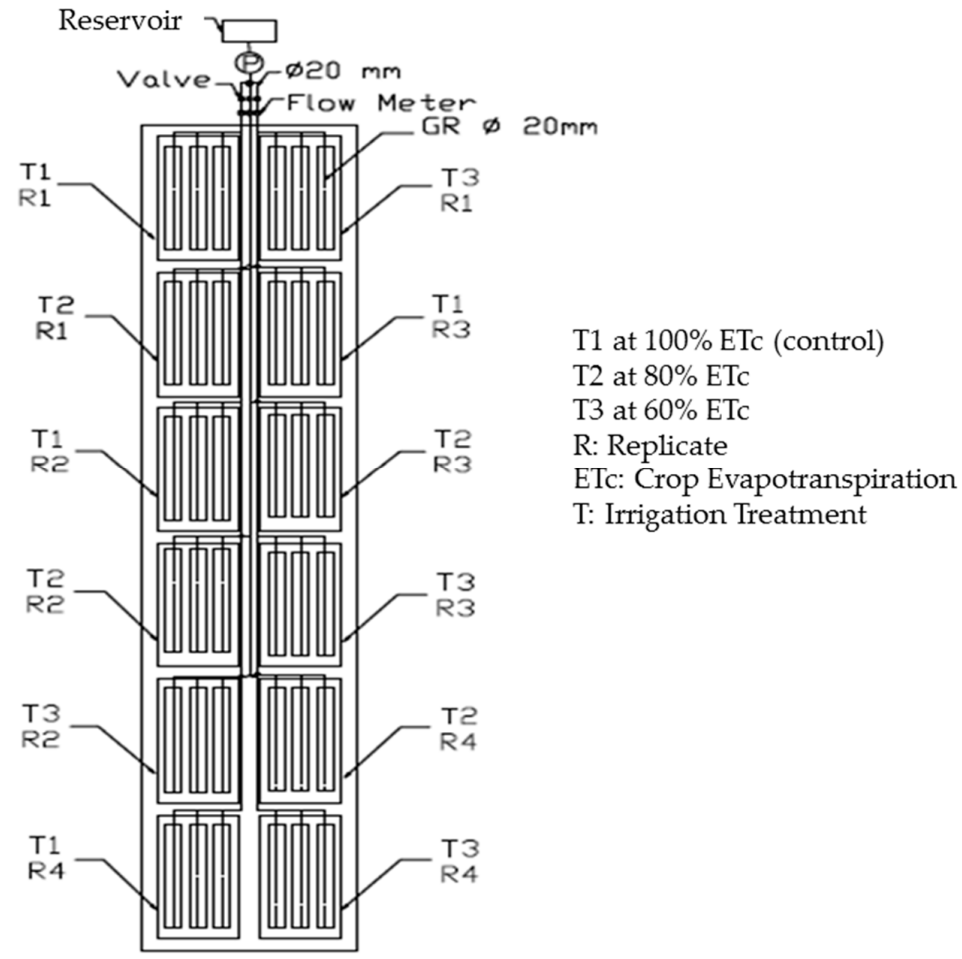

Figure 2. Expriment layout and components of the irrigation system. 


\subsection{Irrigation Measurement}

Evapotranspiration in the greenhouse during the growing season was determined using a Class A evaporation pan (121 cm in diameter and $25.5 \mathrm{~cm}$ in depth) located near the greenhouse. Different methods for determining ET were tested and were found similar in performance; therefore, Class A pan method was chosen, as it is more reliable since it depends on real field measurements. Irrigation was initiated on the basis of the cumulative pan evaporation measured during the interval between irrigations. ETc was calculated by Equation (1):

$$
\mathrm{ETc}=\mathrm{Kc} \times \mathrm{Kp} \times \mathrm{Epan}
$$

where Epan is the amount of cumulative evaporation $(\mathrm{mm})$ during the previous period, $\mathrm{Kp}$ is the pan coefficient, and $\mathrm{Kc}$ is the crop coefficient. The pan and crop coefficients used in this study were taken from reference [27]. The crop ET was determined by multiplying the crop coefficient proposed by reference [28] and the pan coefficient in reference [27] by the evaporation from the pan. According to these studies, $\mathrm{Kp}$ is 0.8 , while $\mathrm{Kc}$ for bell pepper is 0.2 at the initial growing stage, grows linearly to 0.8 after 45 days, reaches 1.15 at the full development stage (60-100 days) and decreases to 0.9 during the latest stage (100-130 days). Table 1 shows the crop coefficient $(\mathrm{Kc})$ and the growth stages. The crop ET under the plastic cover of the greenhouse was reduced by $35 \%$ and was obtained by multiplying crop ET in the open field by a reduction factor, $\mathrm{Kr}$, of 0.65 . The water applied (IR) was calculated as the cumulative ETc under greenhouse divided by $90 \%$, corresponding to the irrigation efficiency of the drip system. A flow meter was installed at the main line feeding each experiment, and thus the irrigation amount for each treatment was recorded and checked against the calculated volume as $\mathrm{Vol}=\mathrm{A} \times \mathrm{IR}$, where $\mathrm{A}$ is the area of the plot in $\mathrm{m}^{2}$.

Table 1. Crop coefficients (Kc) and growth stages.

\begin{tabular}{ccc}
\hline Growth Stage & Period (Days) & Kc Value \\
\hline Initial Stage & $0-30$ & 0.2 \\
Development Stage & $30-60$ & 0.8 \\
Full Stage & $60-100$ & 1.15 \\
Late Stage & $100-130$ & 0.9 \\
\hline
\end{tabular}

\subsection{Fruit Yield and Quality}

The total marketable yield was weighed (g), while fruit diameter (FD) and fruit length (FL), were measured in centimeters using a caliper rule, and the averages of the measured values were recorded. Plant height was measured with a graduated rule. The total soluble solids content in term of sugar content was estimated by measuring the refractive index with a portable refract meter that had been standardized with distilled water. Vitamin C content was calculated on a dry matter basis and was analyzed in the lab of the National Center for Agricultural Research (NCART).

\subsection{Water Use Efficiency and Water Productivity}

Irrigation water use efficiency (IWUE) was calculated as the ratio between the marketable yield harvested $\left(\mathrm{kg} / \mathrm{m}^{2}\right)$ and the total volume of water applied $\left(\mathrm{m}^{3}\right)$. Economic productivity is defined as the value derived per unit of water used, which indicates how much economic output is produced per cubic meter of fresh water abstracted (in $\$$ per $\mathrm{m}^{3}$ ). It serves as a measure of the efficiency of water use.

\subsection{Statistical Analysis}

Statistical analyses were carried out on crop yield, fruit size, sugar content, vitamin C, WUE, WP, and water applied for each treatment, using a regression analysis and PROC/GLM (General Linear Model) procedure of the SAS software (version 9.3, SAS Institute, Inc., Cary, NC, USA). Analysis 
of variance (ANOVA) was conducted, and the significance of differences among treatments was separated using the Least Significant Difference (LSD) at a 5\% probability level. For the statiscal analysis, the hypothesis was:

$H_{0}$ : There is no difference in the average production of sweet pepper among deficit treatments

$H_{a}$ : There is a difference in the average production of sweet pepper among deficit treatments.

The assumptions for using the ANOVA test were:

- There is an independence of treatments

- The distributions of the residuals are normal (Normality)

- There is an equality of variances (homogeneity).

\subsection{Economic Analysis and Financial Feasibility Study}

Managing scarce water resources and improving crop water productivity (CWP) were the main purposes of conducting an economic analysis; the water value that was considered for the economic analysis was based on what farmers paid for the water. To improve crop water productivity, a mathematical formulation was used to examine the effects of water quantity allocation on crop yield and gross margin; a potential crop's water requirement and different regulated deficit irrigation treatments were considered [29], using Equation (2):

$$
\operatorname{Max} Z=\sum_{j} X_{j}\left(G M_{j}-\sum_{i} P_{i} W_{i j}\right)
$$

The research model's mathematical formulation is as follows:

$Z$ = objective function, total gross margin (GM) of land in US \$

$X_{j}=$ total land area of activity $j$

$G M_{j}=$ GM of activity $j$ (US\$),

$P_{i}=$ price of water for month $i\left(\$ / \mathrm{m}^{3}\right)$,

$W_{i j}=$ month i's allocated water quantity for activity $j\left(\mathrm{~m}^{3}\right)$,

where $G M_{j}=\mathrm{TR}-\mathrm{TVC}$,

$\mathrm{TR}=$ Total revenue from the land (\$),

TVC $=$ Total variable cost $(\$)$.

The project's financial feasibility study was done for the overall project's costs and revenues in order to calculate the discounted measurements for each season: net present value (NPV), benefit/cost ratio $(\mathrm{B} / \mathrm{C})$, and internal rate of return (IRR). The fixed expenditures were the cost for the greenhouse, plastic, irrigation system, and pumps. The variable expenditures were the cost of seedlings, fertilizers and pesticides, water, labor, plowing, cans, land, and energy [1]. Then, monetary measurement was applied to all items.

\section{Results}

The bell pepper yields, average weight per fruit, average fruit size, and fruit quality obtained from treatment $1(100 \% \mathrm{ETc})$, treatment $2(80 \%$ of ETc), and treatment $3(60 \% \mathrm{ETc})$ for the winter and spring seasons are presented in Table 2. For the winter season, bell pepper yield response to water applied in $\mathrm{T} 1$ was $10 \%$ higher than that obtained with $\mathrm{T} 2$ and $29.5 \%$ higher than that corresponding to $\mathrm{T} 3$, while, for the spring season, the yield with $\mathrm{T} 1$ was $14 \%$ higher than with $\mathrm{T} 2$ and $35 \%$ higher than with T3, as shown in Figure 3. Irrigation at 100\% of ETc (T1) had a slightly higher yield (34.62 ton/ha) than the other treatments in winter, whereas the yields of T1 and T2 were not significantly different from each other, but both were significantly higher than the yield of T3. In the spring season, there was significant differences among the three treatments. In general, plant yield decreased with the decrease 
of water applied in the two seasons. Figure 3 shows the linear relationships between bell pepper yield and total water applied derived through regression analysis with $\mathrm{R}^{2}$ values of 0.741 and 0.788 for the winter and spring seasons, respectively. The average fruit lengths for the winter season were $14.3 \mathrm{~cm}, 15.6 \mathrm{~cm}$, and $13.6 \mathrm{~cm}$ for T1, T2, and T3, respectively, while, for the spring season, they were $14.6 \mathrm{~cm}, 14.5 \mathrm{~cm}$, and $13.6 \mathrm{~cm}$ for T1, T2, and T3, respectively. The average fruit diameters for the winter season were $6.8 \mathrm{~cm}, 6.85 \mathrm{~cm}$, and $6.4 \mathrm{~cm}$ for T1, T2, and T3, respectively, while, for the spring season, they were $5.9 \mathrm{~cm}, 6.0 \mathrm{~cm}$, and $5.7 \mathrm{~cm}$ for T1, T2, and T3, respectively. The fruit sugar contents on a dry weight basis for the winter season were $5.14 \%, 5.09 \%$, and $5.67 \%$ for $\mathrm{T} 1$, T2, and T3, respectively, while, for the spring season, they were $4.55 \%, 4.62 \%$, and $5.14 \%$ for $\mathrm{T} 1, \mathrm{~T} 2$, and $\mathrm{T} 3$, respectively. The fruit sugar content values for the spring season were relatively lower than those of the winter season by about $11.6 \%$. Vitamin C contents on a dry weight basis for the winter season were 131.6, 142.1, and $152.5 \mathrm{mg} / 100 \mathrm{~g}$ for T1, T2, and T3, respectively, while, for the spring season, they were 125.3, 128.6, and $130.4 \mathrm{mg} / 100 \mathrm{~g}$ for the three treatments, respectively.

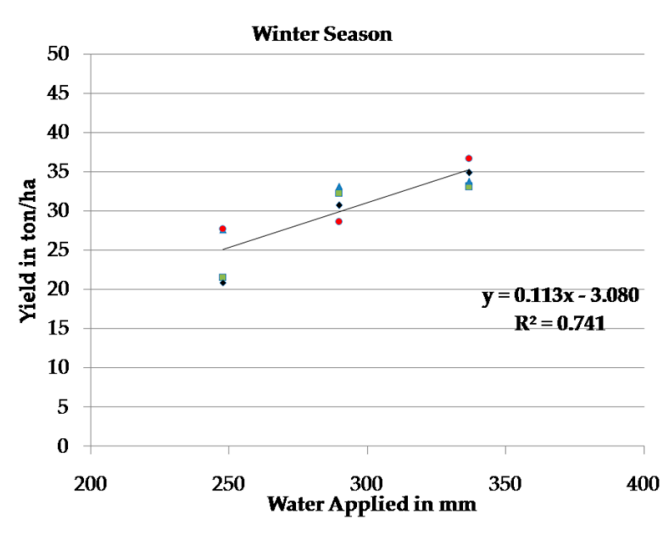

(a)

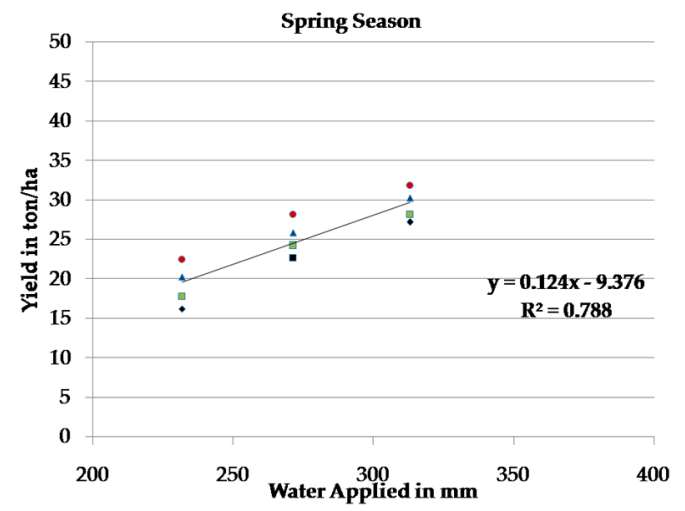

(b)

Figure 3. Total yield of bell pepper versus total water applied in the winter and spring seasons of 2015 and 2016 in the Jordan Valley: (a) Winter season; (b) Spring season.

Table 2. Effects of deficit irrigation on water applied, yield, average fruit size, sugar content, and vitamin C content for bell pepper grown in the Jordan Valley during the winter and spring seasons of 2015 and 2016.

\begin{tabular}{cccccccc}
\hline Season & Treatment & $\begin{array}{c}\text { Water } \\
\text { Applied mm }\end{array}$ & $\begin{array}{c}\text { Yield } \\
\text { ton/ha }\end{array}$ & $\begin{array}{c}\text { Fruit } \\
\text { Length cm }\end{array}$ & $\begin{array}{c}\text { Fruit } \\
\text { Diameter cm }\end{array}$ & $\begin{array}{c}\text { Sugar } \\
\text { Content } \%\end{array}$ & $\begin{array}{c}\text { Vitamin C } \\
\text { mg/100 g }\end{array}$ \\
\hline \multirow{2}{*}{ Winter } & T1 & 336.71 & 34.62 & 14.3 & 6.8 & 5.14 & 131.6 \\
& T2 & 289.74 & 31.20 & 15.6 & 6.8 & 5.09 & 142.1 \\
& T3 & 247.72 & 24.42 & 13.6 & 6.4 & 5.67 & 152.5 \\
\hline \multirow{2}{*}{ Spring } & T1 & 312.95 & 29.36 & 14.6 & 5.9 & 4.55 & 125.3 \\
& T2 & 271.37 & 25.24 & 14.5 & 6.0 & 4.62 & 128.6 \\
& T3 & 231.66 & 19.19 & 13.6 & 5.7 & 5.14 & 130.4 \\
\hline
\end{tabular}

\subsection{Water Use Efficiency and Water Productivity}

Water use efficiency and water productivity values are shown in Table 3 for both seasons. In winter, the WUE and WP values for T1 and T2 were not significantly different from each other $\left(10.28 \mathrm{~kg} / \mathrm{m}^{3}\right.$ and $5.65 \$ / \mathrm{m}^{3}$ for T1 versus $10.77 \mathrm{~kg} / \mathrm{m}^{3}$ and $5.92 \$ / \mathrm{m}^{3}$ for T2), but both were higher than those under $\mathrm{T} 3\left(9.86 \mathrm{~kg} / \mathrm{m}^{3}\right.$ and $\left.5.42 \$ / \mathrm{m}^{3}\right)$. Similar results were obtained for the spring season, with no significant difference between the WUE and WP values between T1 and T2 $\left(9.38 \mathrm{~kg} / \mathrm{m}^{3}\right.$ and $5.16 \$ / \mathrm{m}^{3}$ for T1 vs. $9.3 \mathrm{~kg} / \mathrm{m}^{3}$ and $5.12 \$ / \mathrm{m}^{3}$ for T2), but both values were higher than those under T3 $\left(8.28 \mathrm{~kg} / \mathrm{m}^{3}\right.$ and $4.56 \$ / \mathrm{m}^{3}$ ). Water use efficiency followed the same trend as fruit marketable yield. Figure 4 exhibits the values of WUE and WP for the three treatments and the two seasons as bar charts. Figure 5 shows 
the effect of deficit irrigation on bell pepper water use efficiency and water productivity for the winter and spring seasons of 2015 and 2016 in the Jordan Valley.

Table 3. Effect of deficit irrigation on crop evapotranspiration (ET), water applied, yield, water use efficiency (WUE), water productivity (WP), and water saving on bell pepper grown in the Jordan Valley during the winter and spring seasons of 2015 and 2016.

\begin{tabular}{|c|c|c|c|c|c|c|c|}
\hline Season & Treatment & $\begin{array}{c}\text { Crop ET } \\
\text { mm }\end{array}$ & $\begin{array}{c}\text { Water } \\
\text { Applied mm }\end{array}$ & $\begin{array}{c}\text { Yield } \\
\text { ton/ha }\end{array}$ & $\begin{array}{c}\text { WUE } \\
\mathrm{kg} / \mathrm{m}^{3}\end{array}$ & $\mathrm{WP} \$ / \mathrm{m}^{3}$ & $\begin{array}{c}\text { Water } \\
\text { Saving \% }\end{array}$ \\
\hline \multirow[t]{3}{*}{ Winter } & $\mathrm{T} 1$ & 306.1 & 336.7 & $34.62 \mathrm{~A}$ & 10.28 & 5.65 & 0.0 \\
\hline & $\mathrm{T} 2$ & 263.4 & 289.8 & $31.20 \mathrm{~A}$ & 10.77 & 5.92 & 13.9 \\
\hline & $\mathrm{T} 3$ & 225.2 & 247.7 & 24.42 B & 9.86 & 5.42 & 26.4 \\
\hline \multirow[t]{3}{*}{ Spring } & $\mathrm{T} 1$ & 284.5 & 313.0 & $29.36 \mathrm{~A}$ & 9.38 & 5.16 & 0.0 \\
\hline & $\mathrm{T} 2$ & 246.7 & 271.3 & $25.24 \mathrm{~B}$ & 9.30 & 5.12 & 13.3 \\
\hline & $\mathrm{T} 3$ & 210.6 & 231.7 & $19.19 \mathrm{C}$ & 8.82 & 4.56 & 26.0 \\
\hline
\end{tabular}

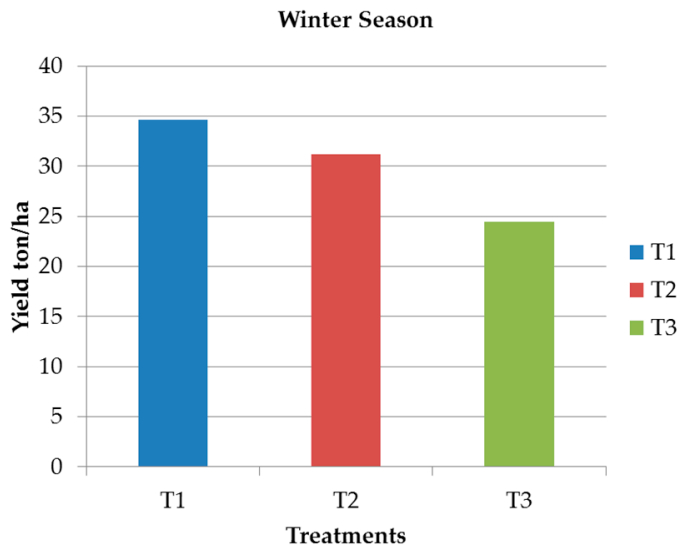

(a)

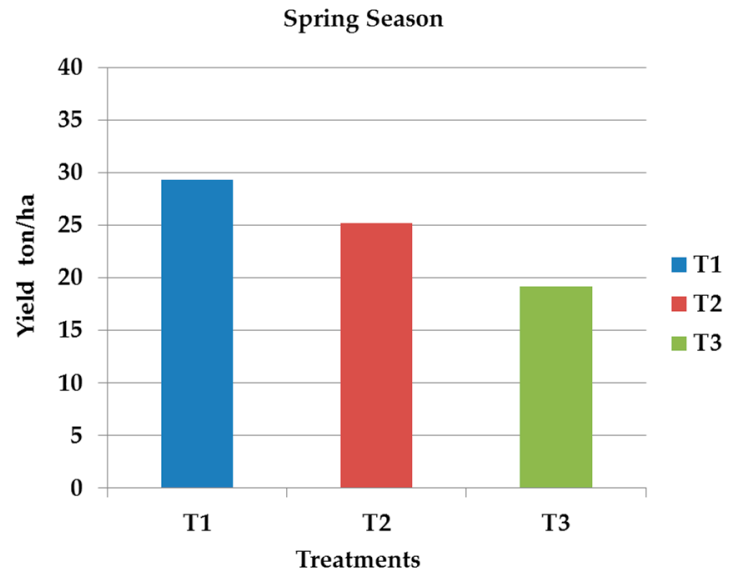

(b)

Figure 4. Effect of deficit irrigation on bell pepper yield in the winter and spring seasons of 2015 and 2016 in the Jordan Valley: (a) Winter season; (b) Spring season.

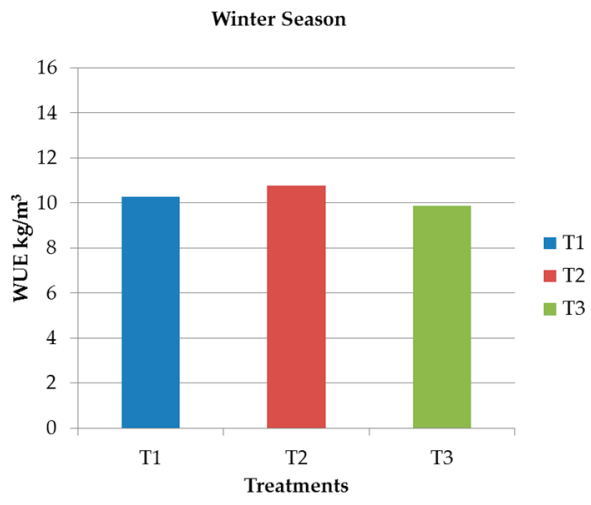

(a)

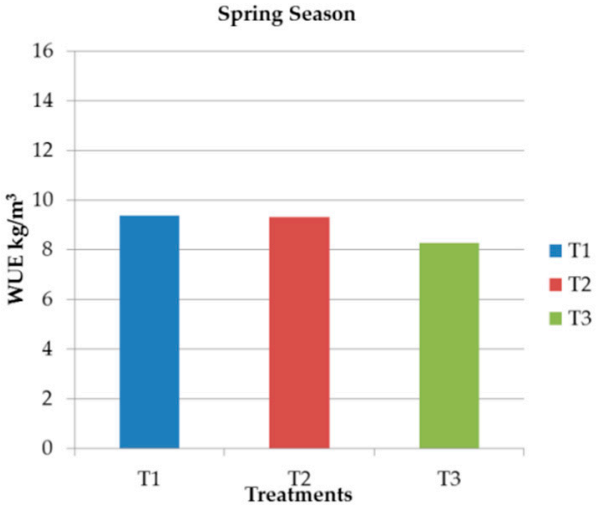

(b)

Figure 5. Effect of deficit irrigation on bell pepper water use effeiency and water productivity in the winter and spring seasons of 2015 and 2016 in the Jordan Valley: (a) Winter season; (b) Spring season.

\subsection{Statistical Analysis}

Tables 4 and 5 show the analysis of variance for the yields obtained during the winter and spring seasons; respectively. For winter season, the statistical analysis showed that there was no significant 
difference at $\mathrm{P}<5 \%$ in the average yield between $\mathrm{T} 1$ and $\mathrm{T} 2$ but there was significant difference between $\mathrm{T} 3$ and the other treatments. For spring season, there were significant differences in yield between the all treatments which indicate that the assumptions of the hypotheses are met.

Table 4. Analysis of variance for the yield of bell pepper obtained during the winter season.

\begin{tabular}{cccccc}
\hline Source of Variation & $\boldsymbol{S S}^{\mathbf{1}}$ & $\boldsymbol{D f}^{\mathbf{2}}$ & $\boldsymbol{M S}^{\mathbf{3}}$ & $\boldsymbol{F}^{\mathbf{4}}$ & $\boldsymbol{P r} \boldsymbol{>} \boldsymbol{F}$ \\
\hline Treatments & 215.606 & 2 & 107.803 & 13.74 & 0.0058 \\
Replicates & 14.312 & 3 & 4.771 & 0.61 & 0.6339 \\
\hline Error & 47.092 & 6 & 7.848 & & \\
Total & 277.010 & 11 & & & \\
\hline & $\mathrm{LSD}^{5}$ at $\mathrm{P}<5 \%=4.178$
\end{tabular}

${ }^{1}$ Sum of Squares of the deviations of the values from the mean; ${ }^{2}$ Degrees of Freedom; ${ }^{3}$ Mean Square; ${ }^{4} F$-value (MS for that row divided by the MS of the error row); ${ }^{5}$ Least Significant Difference.

Table 5. Analysis of variance for the yield of bell pepper obtained during the spring season.

\begin{tabular}{cccccc}
\hline Source of Variation & $\boldsymbol{S S}^{\mathbf{1}}$ & $\boldsymbol{D f}^{\mathbf{2}}$ & $\boldsymbol{M S}^{\mathbf{3}}$ & $\boldsymbol{F}^{\mathbf{4}}$ & $\boldsymbol{P r} \boldsymbol{>} \boldsymbol{F}$ \\
\hline Treatments & 209.341 & 2 & 104.671 & 28.24 & 0.0009 \\
Replicates & 29.912 & 3 & 9.971 & 2.69 & 0.1396 \\
\hline Error & 22.238 & 6 & 3.706 & & \\
Total & 261.491 & 11 & & & \\
\hline & LSD $^{5}$ at $\mathrm{P}<5 \%=3.850$
\end{tabular}

${ }^{1}$ Sum of Squares of the deviations of the values from the mean; ${ }^{2}$ Degrees of Freedom; ${ }^{3}$ Mean Square; ${ }^{4} F$-value (MS for that row divided by the MS of the error row); ${ }^{5}$ Least Significant Difference.

\subsection{Economic Analysis and Financial Feasibility Results}

The results for the two growing seasons are as follows:

Max Z for the winter season in the Jordan Valley $=966.1$

Max $Z$ for the spring season in the Jordan Valley $=629.1$

The feasibility study's results are shown in Tables 6 and 7. The winter season in the Jordan Valley showed the best results for the total gross margin of land with water constraints. The total costs for the two seasons were supposed to be equal. The project's returns varied according to the season and the production amount. The NPV of the Jordan Valley's winter season was 8364.9 \$, and the IRR recovered the total cost plus a $45 \%$ profit, as shown in Table 6, whereas the NPV of the spring season was $304.2 \$$, and the IRR recovered the total cost plus a 13\% profit, as shown in Table 7 . The difference of NPV and IRR between the winter and the spring seasons is attributed to the length of the growing season, corresponding to 130 days in winter and 102 days in spring.

Table 6. Discounted measurements for the Jordan Valley's winter season.

\begin{tabular}{cc}
\hline Discounted Measurements & Value \\
\hline Net present value (NPV) in US\$ & $8364.90 \$$ \\
Benefit/cost ratio (B/C) & 1.29 \\
Internal rate of return (IRR) & $45 \%$ \\
\hline
\end{tabular}

Table 7. Discounted measurements for the Jordan Valley's spring season.

\begin{tabular}{cc}
\hline Discounted Measurements & Value \\
\hline Net present value (NPV) in US\$ & $304.20 \$$ \\
Benefit-cost ratio (B/C) & 1.01 \\
Internal rate of return (IRR) & $13 \%$ \\
\hline
\end{tabular}




\section{Discussion}

The range of irrigation treatments used in this study provided a clear option for evaluating the effect of deficit irrigation on bell pepper yield and other quality parameters, as well as WUE and WP. The yield was highly influenced by the volume of irrigation water applied, resulting in a linear relationship which indicates that more water applied resulted in higher yield. This linear relationship is similar to that found in other studies on bell pepper [26], spinach [30], and tomato [23]. Although there was no significant difference in the marketable yield in the winter season between irrigation levels at $100 \%$ and at $80 \%$ of crop ET, the WUE and WP under the $80 \%$ treatment was slightly higher than that under T1. This indicates that deficit irrigation saved water but did not reduce the yield. For the spring season, the $100 \%$ irrigation treatment (T1) gave the highest yield, while deficit irrigation treatments reduced the yield. However, when taking WUE as an evaluation criterion, there was no difference in WUE between the $100 \%$ and the $80 \%$ treatments, while both WUE values were higher than the WUE under the $60 \%$ treatment by $5.6 \%$. The most water-stressed treatment (T3) had the lowest WUE and WP and the highest fruit total soluble solids content for both seasons. A similar trend was observed for the other results concerning plant height and fruit size and quality. In the same area (the Jordan Valley), deficit irrigation on tomatoes showed that $80 \%$ of full irrigation produced a non-significant yield difference compared to full irrigation [23], but WUE was the highest under $80 \%$ treatment. The highest yield obtained with $100 \%$ ETc (T1) for both seasons is an indication that full irrigation will not cause any stress on the plant, but, on the other hand, irrigation at $80 \%$ ETc produces a non-significant yield reduction and gives higher WUE and WP. Similar finding were reported by studies in Turkey [17], in Egypt [31], and in Syria [19] on bell pepper, bird pepper, and paprika, respectively. Therefore, it is recommended to irrigate bell pepper at $80 \%$ of the calculated ETc because the stress caused by a $20 \%$ reduction in applied water did not reduce yield or WUE significantly.

The yields in the winter season were higher than in spring because the growing season in winter was longer than that in spring (130 day in winter compared to 102 days in spring). The values of WUE and WP for the winter season were also higher than those for the spring season for the same reason. In the Jordan Valley, spring seasons are usually shorter because most vegetables cannot survive the hot temperature of July. Since the two seasons are independent of each other, it is difficult to make a comparison in the first 100 days of each season. Therefore, each season was discussed separately. Bell pepper is cultivated in the Jordan Valley all year round, except during summer (July-September), and has a good market. The economic feasibility analysis helped in factoring all revenues and costs, also taking into the account the timing of each cash flow that can have a large impact on the present value of the revenues and costs. From the economic analysis, it can be concluded that planting bell pepper either in winter or in spring is profitable because the net return of both seasons is higher than the opportunity cost. Economically, as the size of the project increases, the economic benefit increases (economy of scale). If the same project is established in other areas, the profitability will be higher.

\section{Conclusions}

The highest bell pepper yields can be achieved in the greenhouse either with a $100 \%$ or $80 \%$ replenishment of crop evapotranspiration. The highest contents of fruit total soluble solids were found in plant irrigated at 60\% ETc (T3). Decreasing the amount of water applied from $100 \%$ ETc to $80 \%$ ETc and $60 \%$ of ETc improved WUE and WP very slightly, with no significant differences. If the choice criterion is yield, then $80 \%$ ETc irrigation provides the highest yield. However, since no real difference in WUE and WP was found in both seasons, then the crucial evaluation criterion is how much is water is saved. By applying T3 ( $60 \%$ of ETc), about $26 \%$ of water could be saved with a reduction in yield of about $30 \%$ in both seasons, without affecting the WUE and WP. Deficit irrigation provides a good solution for famers in the Jordan Valley to have higher water productivity and irrigation water use efficiency. It also supports the economic development of farms. The winter season showed the best results for the total gross margin of land with water constraints. 
Assuming that the total costs for the two seasons are equal, then the project's returns varied according to the season and the production amount. The NPV for the Jordan Valley's winter season was 8364.90 , and the IRR recovered the total cost plus a 45\% profit. The NPV for the Jordan Valley's spring season was 304.20 \$, and the IRR recovered the total cost plus a 13\% profit. The integration of drip irrigation, crop evapotranspiration, and deficit irrigation has proven its efficacy to improve water productivity compared with the control treatment, due to less irrigation water consumption. Finally, the use of DI practices allows growers to reduce water usage without significant yield loss, while maintaining relatively high WUE and supporting the sustainability of agriculture in the Jordan Valley.

Author Contributions: M.W.S. and M.S. designed the experiments and supervised their execution; M.W.S. handled the agronomic properties of plants and supervised lab analyses; T.Q. carried out the economic and statistical analysis; H.R. followed the agricultural practices in the field.

Funding: This project was carried out with financial support from the European Commission, SRTD-II "Support to Research, Technological Development and Innovation in Jordan" and was managed by the Higher Council for Science and Technology.

Acknowledgments: The authors are grateful to the Higher Council for Science and Technology (HCST) for management and support through the EU-SRTD-II initiative.

Conflicts of Interest: The authors declare no conflict of interest.

\section{References}

1. MWI. Water Sector Capital Investment Plan 2016-2025; Ministry of Water and Irrigation: Amman, Jordan, 2016.

2. Shatanawi, M.; Shammout, M.W.; Naber, S. Water Conflicts among Sectors and Environmental Uses in Jordan. In Mediterranean Seminars, Water Culture and Water Conflict in the Mediterranean Area; OPTIONS Méditerranéennes: Bari, Italy, 2008.

3. MOA. Annual Report of Fruits and Vegetable Exports; Ministry of Agriculture: Amman, Jordan, 2017.

4. Shatanawi, M.; Shammout, M.W. Supply-Demand Modeling of Water Resources in Zarqa River Basin in Jordan. Int. J. Appl. Environ. Sci. (IJAES) 2011, 6, 261-278.

5. Shammout, M.W.; Shatanawi, M.; Naber, S. Participatory Optimization Scenario for Water Resources Management: A Case from Jordan. Water Resour. Manag. 2013, 27, 949-962. [CrossRef]

6. Fereres, E.; Francisco, O.; Victoria, G.-D. Reflections on Food Security under Water Scarcity. J. Exp. Bot. 2011, 62, 4079-4086. [CrossRef] [PubMed]

7. Fereres, E.; Soriano, M.A. Deficit Irrigation for Reducing Agricultural Water Use. J. Exp. Bot. 2007, 58, 147-159. [CrossRef] [PubMed]

8. English, M.J.; Solomon, K.H.; Hoffman, G.J. A Paradigm Shift in Irrigation Management. J. Irrig. Drain. Eng. 2002, 128, 267-277. [CrossRef]

9. English, M.; Nuss, G.S. Designing for Deficit Irrigation. J. Irrig. Drain. Div. 1982, 108, 91-106.

10. Chartzoulakis, K.; Maria, B. Sustainable Water Management in Agriculture under Climate Change. Agric. Agric. Sci. Proc. 2015, 4, 88-95. [CrossRef]

11. Zhang, H. Improving Water Productivity through Deficit Irrigation: Examples from Syria, the North China Plain and Oregon, USA; International Water Management Institute: Colombo, Sri Lanka, 2003.

12. Stewart, D.A.; Nielsen, D.R. (Eds.) Irrigation of Agricultural Crops; Soil Science Society of America Publishers: Madison, WI, USA, 1992.

13. Geets, S.; Kirk, R. Deficit Irrigation as an on-Farm Strategy to Maximize Crop Water Productivity in Dry Areas. Agric. Water Manag. 2009, 96, 1275-1284. [CrossRef]

14. Evett, S.R.; Tolk, J.A. Introduction: Can Water Use Efficiency Be Modeled Well Enough to Impact Crop Management? Agron. J. 2009, 3, 423-425. [CrossRef]

15. Kato, Y.; Abe, J.; Kamoshita, A.; Yamagishi, J. Genotypic Variation in Root Growth Angle in Rice (Oryza sativa L.) and Its Association with Deep Root Development in Upland Fields with Different Water Regimes. Plant Soil 2006, 287, 117-129. [CrossRef]

16. FAO. Deficit Irrigation Practices. In FAO Water Report no 22; FAO: Rome, Italy, 2002.

17. Demirtas, C.; Ayas, S. Deficit Irrigation Effects on Pepper (Capsicum annuum L. Demre) Yield in Unheated Greenhouse Condition. J. Food Agric. Environ. 2009, 7, 989-993. 
18. Gonzalez-Dugo, V.; Orgaz, F.; Fereres, E. Responses of Pepper to Deficit Irrigation for Paprika Production. Sci. Hortic. 2007, 114, 77-82. [CrossRef]

19. Bladia, R.; AbdArahman, S. Effect of Water Stress on Pepper Plant (Capsicum annum) Var Albaladi. J. Al-Baath Univ. 2016, 38, 103-117.

20. Ayas, S. The Effects of Irrigation Regimes on the Yield and Water Use of Eggplant (Solanum melongena L.). Soil Water J. 2007, 6, 49-58. [CrossRef]

21. Bani Hani, N. Evapotranspiration, Growth and Yield of Navel Oranges under Two Levels of Deficit Irrigation; The University of Jordan: Amman, Jordan, 2008.

22. Shatanawi, M.R.; Suleiman, A.A.; Al-Bakri, J. Effect of Deficit Irrigation on Lemon Water Requirements and Yield in the Jordan Valley. Jordan J. Agric. Sci. 2011, 7, 564-574.

23. Al-Qerem, R.A.; Suleiman, A.A.; Shatanawi, M.R. Assessing Tomato Yield and Water Saving under Deficit Irrigation in the Jordan Valley. Jordan J. Agric. Sci. 2012, 8, 209-222.

24. Yildirim, M.; Demirel, K.; Bahar, E. Effect of Restricted Water Supply and Stress Development on Growth of Bell Pepper (Capsicum annuum L.) under Drought Conditions. J. Agron. Crop Sci. 2012, 3, 19.

25. Zotarelli, L.; Dukes, M.; Scholberg, J.; Femminella, K.; Munoz-Carpena, R. Irrigation Scheduling for Green Bell Peppers Using Capacitance Soil Moisture Sensors. J. Irrig. Drain. Eng. 2011, 137, 73-81. [CrossRef]

26. Aladenola, O.; Madramootoo, C. Response of Greenhouse-Grown Bell Pepper (Capsicum annuum L.) to Variable Irrigation. Can. J. Plant Sci. 2014, 94, 303-310. [CrossRef]

27. Allen, R.G.; Pereira, L.S.; Raes, D.; Smith, M. Crop Evapotranspiration: Guidelines for Computing Crop Water Requirements. In FAO Irrigation and Drainage Paper, No 56; FAO: Rome, Italy, 1998.

28. Orgaz, F.; Fernandez, M.D.; Bonachela, S.; Gallardo, M.; Fereres, E. Evapotranspiration of Horticultural Crops in an Unheated Plastic Greenhouse. Agric. Water Manag. 2005, 72, 81-96. [CrossRef]

29. Van Den Berg, C.; Al-Nimer, A.; Fileccia, S.; Gonzalez, T.; Maria, L.; Wahseh, S. The Cost of Irrigation Water in the Jordan Valley; Water Partnership Program (WPP), World Bank Group: Washington, DC, USA, 2016.

30. Leskovar, D.I.; Piccinni, G. Yield and Leaf Quality of Processing Spinach under Deficit Irrigation. Hortscience 2005, 40, 1868-1870.

31. Ismail, S.M. Water Use Efficiency and Bird Pepper Production as Affected by Deficit Irrigation Practice. Int. J. Agric. For. 2012, 2, 262-267. [CrossRef]

(C) 2018 by the authors. Licensee MDPI, Basel, Switzerland. This article is an open access article distributed under the terms and conditions of the Creative Commons Attribution (CC BY) license (http:/ / creativecommons.org/licenses/by/4.0/). 